\title{
Oceanobacillus profundus sp. nov., isolated from a deep-sea sediment core
}

\author{
Yoon-Gon Kim, ${ }^{1}$ Dong Han Choi, ${ }^{1}+$ Sangmin Hyun ${ }^{2}$ and Byung Cheol Cho ${ }^{1}$ \\ ${ }^{1}$ School of Earth and Environmental Sciences and Research Institute of Oceanography, Seoul \\ National University, San 56-1 Shillim-dong, Kwanak-gu, Seoul 151-742, Republic of Korea \\ ${ }^{2}$ South Sea Institute/Korea Ocean Research and Development Institute (KORDI), 391 Jang \\ mok-ri, Jangmok-myon, Geoje 656-830, Republic of Korea
}

Correspondence

Byung Cheol Cho

bccho@snu.ac.kr

\begin{abstract}
A halotolerant, facultatively alkaliphilic bacterium, designated CL-MP28 ${ }^{\top}$, was isolated from the surface of a sediment core sample collected at a depth of $2247 \mathrm{~m}$ in the Ulleung Basin of the East Sea, Korea. Phylogenetic analysis of the $16 \mathrm{~S}$ rRNA gene sequence of strain CL-MP28 ${ }^{\top}$ revealed an affiliation with the genus Oceanobacillus. The sequence similarities between the isolate and type strains of members of the genus Oceanobacillus were in the range 95.0-96.0\%, indicating that strain CL-MP28 ${ }^{\top}$ represented a novel species within the genus. The strain was found to be Gram-positive, rod-shaped and motile by means of peritrichous flagella and was shown to produce ellipsoidal spores. The strain was strictly aerobic and able to grow with $\mathrm{NaCl}$ at concentrations in the range $0-14 \%(\mathrm{w} / \mathrm{v})$ at $\mathrm{pH} 7.5$. The strain grew at temperatures of $15-42{ }^{\circ} \mathrm{C}$ and at $\mathrm{pH}$ 6.5-9.5. The major fatty acids were anteiso- $\mathrm{C}_{15: 0}(64.9 \%)$, anteiso- $\mathrm{C}_{17: 0}(11.9 \%)$ and iso- $\mathrm{C}_{16: 0}(7.7 \%)$. The major isoprenoid quinone was MK-7. The DNA G $+\mathrm{C}$ content was $40.2 \mathrm{~mol} \%$. According to the $16 \mathrm{~S}$ rRNA gene sequence, DNA-DNA relatedness and physiological data and the fatty acid composition, CL-MP28 ${ }^{\top}$ could be assigned to the genus Oceanobacillus, but is distinguishable from the recognized species of this genus. Strain CL-MP28 ${ }^{\top}$ therefore represents a novel species within the genus Oceanobacillus, for which the name Oceanobacillus

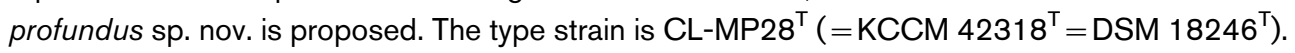

The genus Oceanobacillus was first proposed with the single species Oceanobacillus iheyensis, which was isolated from a deep-sea mud sample collected at a depth of $1050 \mathrm{~m}$ on the Iheya Ridge of the Nansei Islands and demonstrated an extremely halotolerant and facultatively alkaliphilic phenotype (Lu et al., 2001). The genus description was later emended with the isolation of a halotolerant obligate alkaliphile, Oceanobacillus oncorhynchi, isolated from the skin of a rainbow trout (Oncorhynchus mykiss) (Yumoto et al., 2005). Recently, [Virgibacillus] picturae, isolated from deteriorated mural paintings (Heyrman et al. 2003), was reclassified as Oceanobacillus picturae (Lee et al., 2006). Thus, the genus Oceanobacillus currently comprises three species, comprising motile, Gram-positive rods that produce ellipsoidal endospores within swollen sporangia (Lee et al., 2006).

tPresent address: Marine Environmental Research Department, KORDI, Ansan 426-744, Republic of Korea

The GenBank/EMBL/DDBJ accession number for the 16S rRNA gene sequence of strain CL-MP28 ${ }^{\top}$ is DQ386635.

Details of the whole-cell fatty acid compositions of strain CL-MP28 ${ }^{\top}$ and related Oceanobacillus species are available in a supplementary table in IJSEM Online.
In this study, a novel strain, CL-MP $28^{\mathrm{T}}$, was isolated from the surface of a sediment core sample collected at depth of $2247 \mathrm{~m}$ in the Ulleung Basin of the East Sea, Korea. The sediment slurry was spread on a plate containing marine agar 2216 (Difco) and incubated at $20^{\circ} \mathrm{C}$ for 2 weeks. Strain CL-MP $28^{\mathrm{T}}$ was isolated on the plate and subsequently purified on marine agar 2216 at $30{ }^{\circ} \mathrm{C}$ four times. The strain was maintained at $-80{ }^{\circ} \mathrm{C}$ both on marine agar 2216 at $4{ }^{\circ} \mathrm{C}$ and in marine broth 2216 (Difco) supplemented with $30 \%$ (v/v) glycerol.

The 16S rRNA gene was amplified from a single colony by a PCR with Taq DNA polymerase (Bioneer) and primers $27 \mathrm{~F}$ and 1492R (Lane, 1991). The PCR product was purified using an AccuPrep PCR purification kit (Bioneer). Sequencing of the 16S rRNA gene was performed with an Applied Biosystems automatic sequencer (ABI3730XL) at Macrogen Corp. (Seoul, Korea). An almost-complete 16S rRNA gene sequence (1354 bp) of strain CL-MP28 ${ }^{\mathrm{T}}$ was obtained. This sequence was compared with those available in GenBank by using BLASTN (Altschul et al., 1990) searches. The sequence of strain CL-MP $28^{\mathrm{T}}$ was manually aligned with those of the type strains of the three Oceanobacillus species and with those of the type species of other genera in the family Bacillaceae, obtained from GenBank and the 
Ribosomal Database Project (Cole et al., 2003) databases using known $16 \mathrm{~S}$ rRNA secondary structure information. Phylogenetic trees were obtained by using the neighbourjoining (Saitou \& Nei, 1987), maximum-parsimony (Fitch, 1971) and maximum-likelihood (Felsenstein, 1981) methods. An evolutionary distance matrix for the neighbourjoining method was generated according to the model of Jukes \& Cantor (1969). The robustness of the tree topologies was assessed by using bootstrap analyses based on 1000 replications (for the neighbour-joining and maximumparsimony methods) or 100 replications (for the maximumlikelihood method). Alignment analyses were carried out using the jPHYDIT program (Jeon et al., 2005), and phylogenetic analysis were carried out using MEGA3 (Kumar et al., 2004) and PAUP* 4.0 (Swofford, 1998). Likelihood parameters were estimated by means of the hierarchical ratio tests in MODELTEST, version 3.04 (Posada \& Crandall, 1998). The sequence similarities indicated that the closest relatives of strain CL-MP28 ${ }^{\mathrm{T}}$ were O. iheyensis JCM $11309^{\mathrm{T}}(95.96 \%)$ and O. oncorhynchi R-2 ${ }^{\mathrm{T}}(95.48 \%)$. Phylogenetic analyses based on the 16S rRNA gene sequence showed that strain CL-MP $28^{\mathrm{T}}$ formed a robust cluster with species of the genus Oceanobacillus (Fig. 1). Thus, it is clear that our isolate belongs to the genus Oceanobacillus. However, the low levels of similarity (95.0-96.0 \%) between the 16S rRNA gene sequence of the novel isolate and those of previously described species of the genus Oceanobacillus indicated that strain CL-MP $28^{\mathrm{T}}$ represents a novel species of the genus (Stackebrandt \& Goebel, 1994; Rosselló-Mora \& Amann, 2001). The relatedness of the genomic DNA was determined by means of dot-blot hybridization. Probe DNA labelling was performed using a nick translation kit (Roche), and hybridization and detection were done using the DIG labelling and detection kit (Roche) according to the manufacturer's instruction. The level of DNA-DNA relatedness between strain CL-MP2 $8^{\mathrm{T}}$ and $O$. iheyensis KCTC $3954^{\mathrm{T}}$ was $24.7 \%$, while that for O. oncorhynchi $\mathrm{R}-2^{\mathrm{T}}$ was $17.5 \%$. These values are below the currently accepted limit for DNA relatedness $(70 \%)$ for the phylogenetic definition of a species (Stackebrandt \& Goebel, 1994) and therefore provide evidence that our isolate (CL-MP28 ${ }^{\mathrm{T}}$ ) represents a novel species of the genus Oceanobacillus. The DNA G $+\mathrm{C}$ content was determined by HPLC analysis (Tamaoka \& Komagata, 1984) at the Korean Culture Center of Microorganisms (Seoul, Korea) and was found to be $40.2 \mathrm{~mol} \%$.

For the phenotypic and chemotaxonomic analyses, strain CL-MP28 ${ }^{\mathrm{T}}$ was routinely cultivated on PYA medium ( $1 \%$ peptone, $0.5 \%$ yeast extract, $0.1 \% \quad \mathrm{~K}_{2} \mathrm{HPO}_{4}, \quad 0.02 \%$ $\mathrm{MgSO}_{4} .7 \mathrm{H}_{2} \mathrm{O}, 3 \% \mathrm{NaCl}, 1.5 \%$ Bacto agar, pH 7.5; $\mathrm{Lu}$ et al., 2001). Gram-staining was performed as described by Smibert \& Krieg (1994). The cell morphology was examined using phase-contrast microscopy and transmission electron microscopy (EX2; JEOL) with cells grown at $30{ }^{\circ} \mathrm{C}$ on a PYA agar plate. Electron microscopy showed that the cells were peritrichously flagellated rods $(0.2-0.4 \times 0.8-2 \mu \mathrm{m})$. Anaerobic growth was checked on PYA using the GasPak anaerobic system (BBL) for 12 days. Hydrolysis of casein, DNA and Tweens 40, 60 and 80 and catalase and oxidase activities were determined according to the protocols described by Barrow \& Feltham (1993). Other enzyme activities were also assayed using the API 20NE system (bioMérieux) according to the manufacturer's instruction, except that cell suspensions were prepared using a $3 \%(\mathrm{w} / \mathrm{v})$ $\mathrm{NaCl}$ solution. Acid production from various carbohydrates was determined by employing the API $50 \mathrm{CH}$ system (bioMérieux) according to the manufacturer's instructions. All suspension media were supplemented with $3 \% \mathrm{NaCl}$ (final concentration). For the API $20 \mathrm{NE}$ and API $50 \mathrm{CH}$ analyses, O. iheyensis KCTC $3954^{\mathrm{T}}$ was used as a reference strain. The temperature range for growth was determined using PYA broth (the same composition as PYA but without the agar) incubated at various temperatures in the range $5-40{ }^{\circ} \mathrm{C}$ (using increments of $5{ }^{\circ} \mathrm{C}$ ) and at $40-45^{\circ} \mathrm{C}$ (using increments of $1^{\circ} \mathrm{C}$ ). PYA broth and PYA broth containing $100 \mathrm{mM} \mathrm{NaHCO} / \mathrm{Na}_{2} \mathrm{CO}_{3}$ were used, respectively, for growth experiments at $\mathrm{pH} 6.0-8.5$ and $\mathrm{pH} 9.0-10.5$. Final $\mathrm{pH}$ was adjusted with $\mathrm{HCl}$ or $\mathrm{NaOH}$ solution. The $\mathrm{NaCl}$ concentrations allowing growth of strain CL-MP2 $8^{\mathrm{T}}$ were

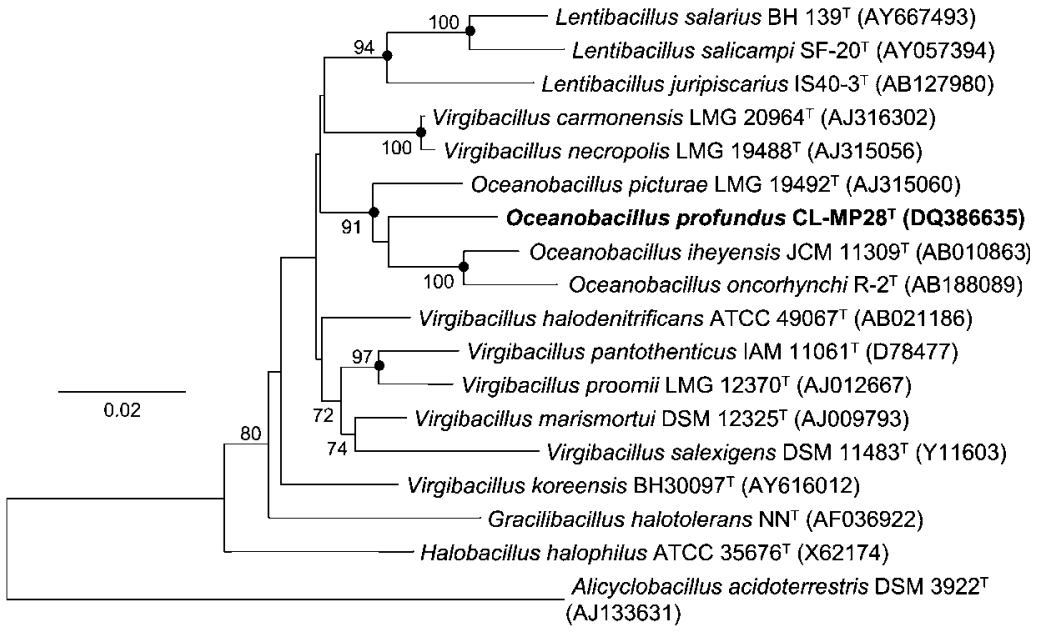

Fig. 1. Neighbour-joining phylogenetic tree, based on 16S rRNA gene sequences, showing the position of strain CL-MP28 ${ }^{\top}$ with respect to Oceanobacillus species and related taxa. Only bootstrap percentages above $60 \%$ are shown (1000 resamplings) at branching points. Filled circles indicate that the corresponding nodes were also recovered in the maximum-likelihood and maximum-parsimony trees. Bar, 0.02 nucleotide substitutions per site. 
determined by using PYA broth supplemented with various $\mathrm{NaCl}$ concentrations $(0,1,2,3,5,7,8,10,13,15,18,20,21$, 22 and $25 \%$, w/v). All media were sterilized with sterile $0.22 \mu \mathrm{m}$ pore-size syringe filters (Adventec MFS). Growth at different $\mathrm{pHs}, \mathrm{NaCl}$ concentrations and temperatures was measured by monitoring changes in $\mathrm{OD}_{600}$ over time. All of the experiments were performed under aerobic conditions. The isolate was revealed to be Gram-positive and to produce ellipsoidal spores positioned terminally within swollen sporangia. The acid production from amygdalin demonstrated by strain CL-MP $28^{\mathrm{T}}$ differentiates it from the recognized species of the genus Oceanobacillus; furthermore, the species of the genus can be clearly distinguished from each other using a minimal combination of phenotypic characteristics ( $\beta$-galactosidase and gelatinase) (Table 1). The morphological, physiological and biochemical characteristics of the isolate are given in Table 1 and in the species description.

Isoprenoid quinones were isolated according to Minnikin et al. (1984) and analysed by HPLC as described by Collins (1985). The major isoprenoid quinone in CL-MP28 ${ }^{\mathrm{T}}$ is MK7. The fatty acid methyl esters present in whole cells grown on PYA at $27^{\circ} \mathrm{C}$ for $48 \mathrm{~h}$ were analysed by gas chromatography according to the instructions of the Microbial Identification System (MIDI) at the Korean Culture Center of Microorganisms. The fatty acid profile of CL-MP28 ${ }^{\mathrm{T}}$ was dominated by branched fatty acids: anteiso- $\mathrm{C}_{15: 0}(64.9 \%)$,

Table 1. Differential phenotypic characteristics of strain CL-MP28 ${ }^{\top}$ and related Oceanobacillus species

Strains: 1, CL-MP28 ${ }^{\mathrm{T}}$ (this study); 2, O. iheyensis KCTC $3954^{\mathrm{T}}$ (unless indicated, data from Lu et al., 2001); 3, O. oncorhynchi R-2 ${ }^{\mathrm{T}}$ (Yumoto et al., 2005); 4, O. picturae KCTC $3821^{\mathrm{T}}$ (Heyrman et al., 2003). +, Positive; -, negative; W, weakly positive; vw, very weakly positive; ND, not determined; All strains are motile, Gram-positive, oxidase- and catalase-positive and produce ellipsoid spores and are negative for indole production. None of the strains produced acid from D-arabinose, L-rhamnose, myo-inositol, L-fucose or 5-keto-D-gluconate.

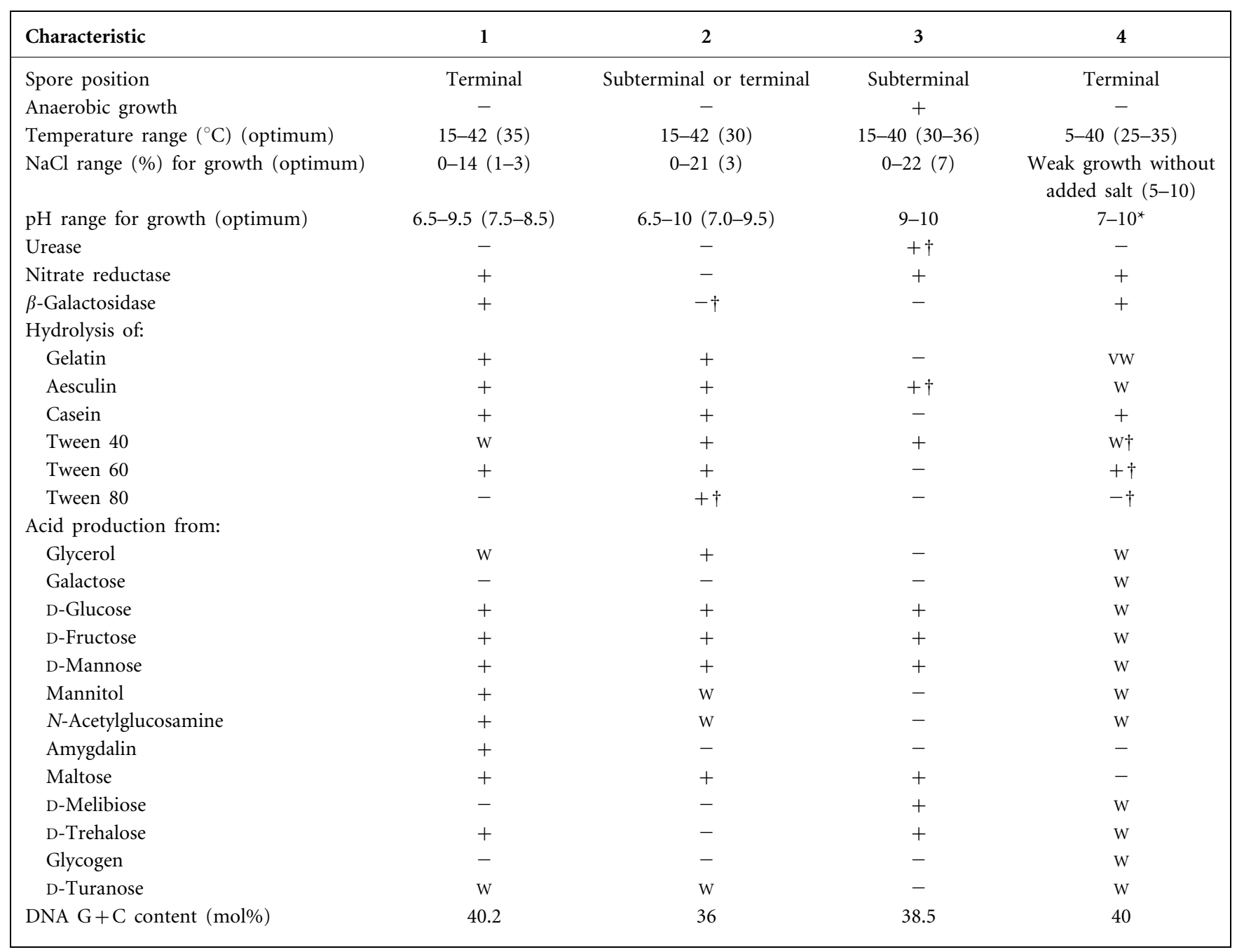

${ }^{\star}$ Data from Lee et al. (2006).

$\dagger$ Data from this study: O. oncorhynchi $\mathrm{R}-2^{\mathrm{T}}$ was tested with API $20 \mathrm{NE}$, using a suspension medium supplemented with $7 \% \mathrm{NaCl}$ (at $\mathrm{pH} 10$ ). 
anteiso- $\mathrm{C}_{17: 0}(11.9 \%)$, iso- $\mathrm{C}_{16: 0}(7.7 \%)$, iso- $\mathrm{C}_{14: 0}(5.6 \%)$ and iso- $\mathrm{C}_{15: 0}(3.8 \%)$ (see Supplementary Table S1 available in IJSEM Online). The relative proportions of the predominant fatty acids in CL-MP28 ${ }^{\mathrm{T}}$ were different from those of O. iheyensis KCTC $3954^{\mathrm{T}}$ and O. oncorhynchi $\mathrm{R}-2^{\mathrm{T}}$, but were relatively similar to those of $O$. picturae KCTC $3821^{\mathrm{T}}$. However, the absence of summed feature 7 $\left(\mathrm{C}_{18: 1} \omega 7 c, \mathrm{C}_{18: 1} \omega 9 t\right.$ and/or $\left.\mathrm{C}_{18: 1} \omega 12 t\right)$, the relatively low optimal $\mathrm{NaCl}$ concentration for growth and the lack of growth at temperatures below $15^{\circ} \mathrm{C}$ of strain CL-MP28 ${ }^{\mathrm{T}}$ differentiate it from O. picturae KCTC $3821^{\mathrm{T}}$.

Some phenotypic characteristics of strain CL-MP28 ${ }^{\mathrm{T}}$, e.g. acid production from amygdalin and a relatively low optimal $\mathrm{NaCl}$ concentration for growth, clearly distinguish the novel isolate from previously described species of the genus Oceanobacillus. Furthermore, the DNA-DNA relatedness data supported our suggestion that strain CL-MP28 ${ }^{\mathrm{T}}$ should be classified within a novel species within the genus Oceanobacillus (Stackebrandt \& Goebel, 1994). In conclusion, phylogenetic analyses based on $16 \mathrm{~S}$ rRNA gene sequences, DNA-DNA relatedness and physiological and chemotaxonomic features suggest that strain CL-MP28 ${ }^{\mathrm{T}}$ represents a novel species of the genus Oceanobacillus, for which the name Oceanobacillus profundus sp. nov. is proposed.

\section{Description of Oceanobacillus profundus sp. nov.}

Oceanobacillus profundus (pro.fun'dus. L. masc. adj. profundus from the deep).

Cells are Gram-positive, peritrichously flagellated, straight rods that are approximately $0.2-0.4 \times 0.8-2 \mu \mathrm{m}$ in size and produce ellipsoidal spores terminally positioned within swollen sporangia. Colonies are circular and creamy white in colour. Obligately aerobic or facultatively alkaliphilic. Grows at $15-42{ }^{\circ} \mathrm{C}$ (optimum $35^{\circ} \mathrm{C}$ ) and $\mathrm{pH}$ 6.5-9.5 (optimum $\mathrm{pH}$ 7.5-8.5). Catalase- and oxidase-positive. The $\mathrm{NaCl}$ range for growth is $0-14 \%(\mathrm{w} / \mathrm{v})$ at $\mathrm{pH} 7.5$ (optimum 1-3\%). Nitrate reductase, $\beta$-galactosidase (ONPG) and DNase activities are present and hydrolysis of gelatin, aesculin, casein and Tweens 40 and 60 is demonstrated. Indole production, urease and hydrolysis of Tween 80 are absent. Acids are produced from glycerol, Dxylose, D-glucose, D-fructose, D-mannose, mannitol, $\mathrm{N}$ acetylglucosamine, amygdalin, maltose, lactose, D-trehalose and D-turanose, but not from D-arabinose, galactose, Lrhamnose, myo-inositol, D-melibiose, glycogen or L-fucose. The DNA G + C content is $40.2 \mathrm{~mol} \%$. The major fatty acids are anteiso- $\mathrm{C}_{15: 0}(64.9 \%)$, anteiso- $\mathrm{C}_{17: 0}(11.9 \%)$, iso$\mathrm{C}_{16: 0}(7.7 \%)$, iso- $\mathrm{C}_{14: 0}(5.6 \%)$, iso- $\mathrm{C}_{15: 0}(3.8 \%)$ and $\mathrm{C}_{16: 0}$ $(2.5 \%)$. The major isoprenoid quinone is MK-7.

The type strain, CL-MP28 $8^{\mathrm{T}}\left(=\mathrm{KCCM} 42318^{\mathrm{T}}=\mathrm{DSM}\right.$ $18246^{\mathrm{T}}$ ), was isolated from the surface of a sediment core sample collected at a depth of $2247 \mathrm{~m}$ in the Ulleung Basin of the East Sea, Korea.

\section{Acknowledgements}

This work was supported, in part, by the BK21 project of the Korean Government and a KORDI project (PG43802).

\section{References}

Altschul, S. F., Gish, W., Miller, W., Myers, E. W. \& Lipman, D. J. (1990). Basic local alignment search tool. J Mol Biol 215, 403-410.

Barrow, G. I. \& Feltham, R. K. A. (1993). Cowan and Steel's Manual for the Identification of Medical Bacteria, 3rd edn. Cambridge: Cambridge University Press.

Cole, J. R., Chai, B., Marsh, T. L., Farris, R. J., Wang, Q., Kulam, S. A., Chandra, S., McGarrell, D. M., Schmidt, T. M. \& other authors (2003). The Ribosomal Database Project (RDP-II): previewing a new autoaligner that allows regular updates and the new prokaryotic taxonomy. Nucleic Acids Res 31, 442-443.

Collins, M. D. (1985). Analysis of isoprenoid quinones. Methods Microbiol 18, 329-366.

Felsenstein, J. (1981). Evolutionary trees from DNA sequences: a maximum likelihood approach. J Mol Evol 17, 368-376.

Fitch, W. M. (1971). Toward defining the course of evolution: minimum change for a specific tree topology. Syst Zool 20, 406-416.

Heyrman, J., Logan, N. A., Busse, H.-J., Balcaen, A., Lebbe, L., Rodriguez-Diaz, M., Swings, J. \& De Vos, P. (2003). Virgibacillus carmonensis sp. nov., Virgibacillus necropolis sp. nov. and Virgibacillus picturae sp. nov., three novel species isolated from deteriorated mural paintings, transfer of the species of the genus Salibacillus to Virgibacillus, as Virgibacillus marismortui comb. nov. and Virgibacillus salexigens comb. nov., and emended description of the genus Virgibacillus. Int J Syst Evol Microbiol 53, 501-511.

Jeon, Y. S., Chung, H. W., Park, S., Hur, I., Lee, J. H. \& Chun, J. (2005). jPHYDIT: a JAVA-based integrated environment for molecular phylogeny of ribosomal RNA sequences. Bioinformatics 21, 3171-3173.

Jukes, T. H. \& Cantor, C. R. (1969). Evolution of protein molecules. In Mammalian Protein Metabolism, pp. 21-132. Edited by H. N. Munro. New York: Academic Press.

Kumar, S., Tamura, K. \& Nei, M. (2004). MEGA3: integrated software for molecular evolutionary genetics analysis and sequence alignment. Brief Bioinform 5, 150-163.

Lane, D. J. (1991). 16S/23S rRNA sequencing. In Nucleic Acid Techniques in Bacterial Systematics, pp. 115-175. Edited by E. Stackebrandt \& M. Goodfellow. Chichester: Wiley.

Lee, J. S., Lim, J. M., Lee, K. C., Lee, J. C., Park, Y. H. \& Kim, C. J. (2006). Virgibacillus koreensis sp. nov., a novel bacterium from a salt field, and transfer of Virgibacillus picturae to the genus Oceanobacillus as Oceanobacillus picturae comb. nov. with emended descriptions. Int J Syst Evol Microbiol 56, 251-257.

Lu, J., Nogi, Y. \& Takami, H. (2001). Oceanobacillus iheyensis gen. nov., sp. nov., a deep-sea extremely halotolerant and alkaliphilic species isolated from a depth of $1050 \mathrm{~m}$ on the Iheya Ridge. FEMS Microbiol Lett 205, 291-297.

Minnikin, D. E., O'Donnell, A. G., Goodfellow, M., Alderson, G., Athalye, M., Schaal, K. \& Parlett, J. H. (1984). An integrated procedure for the extraction of bacterial isoprenoid quinones and polar lipids. J Microbiol Methods 2, 233-241.

Posada, D. \& Crandall, K. A. (1998). MODELTEST: testing the model of DNA substitution. Bioinformatics 14, 817-818.

Rosselló-Mora, R. \& Amann, R. (2001). The species concept for prokaryotes. FEMS Microbiol Rev 25, 39-67. 
Saitou, N. \& Nei, M. (1987). The neighbor-joining method: a new method for reconstructing phylogenetic trees. Mol Biol Evol 4, 406-425.

Smibert, R. M. \& Krieg, N. R. (1994). Phenotypic characterization. In Methods for General and Molecular Bacteriology, pp. 607-654. Edited by P. Gerhardt, R. G. E. Murray, W. A. Wood \& N. R. Krieg. Washington, DC: American Society for Microbiology.

Stackebrandt, E. \& Goebel, B. M. (1994). Taxonomic note: a place for DNA-DNA reassociation and 16S rRNA sequence analysis in the present species definition in bacteriology. Int J Syst Bacteriol 44, 846-849.
Swofford, D. L. (1998). PAUP*: phylogenetic analysis using parsimony, version 4. Sunderland, MA: Sinauer Associates.

Tamaoka, J. \& Komagata, K. (1984). Determination of DNA base composition by reverse-phase high performance liquid chromatography. FEMS Microbiol Lett 25, 125-128.

Yumoto, I., Horota, K., Nodasaka, Y. \& Nakajima, K. (2005). Oceanobacillus oncorhynchi sp. nov., a halotolerant obligate alkaliphile isolated from the skin of a rainbow trout (Oncorhynchus mykiss), and emended description of the genus Oceanobacillus. Int J Syst Evol Microbiol 55, 1521-1524. 